\title{
Political ecology of Jharkhand conflicts
}

\author{
Sarah Jewitt \\ School of Geography, University of Nottingham, University Park, Nottingham NG7 2RD, UK. \\ Email: sarah.jewitt@nottingham.ac.uk
}

\begin{abstract}
Although India's Jharkhand movement resists classification as either an ethnic or an environmental movement, it has, at different times, mobilised clear elements of both with frequently violent outcomes. This paper examines the movement from a political ecology perspective and focuses on violence arising from natural resource-related grievances, notably land alienation, forest policy and employment from Jharkhand's mines. Drawing from political ecology's emphasis on the need to examine conflict from a range of different spatial scales, the paper emphasises the importance of a micro-political ecology approach for understanding how locally based conflicts over natural resources can harden into more established grievances that can be mobilised politically as part of a wider and potentially violent protest movement. It is also suggested that micro-political ecology approaches can assist participatory resource management initiatives in ameliorating local conflicts over access to resources, thus helping to prevent them from escalating into more widespread violence.
\end{abstract}

Keywords: forests, India, Jharkhand, political ecology, violence

\section{Introduction}

Throughout much of the twentieth century, local politics within the Jharkhand region of India were strongly influenced by a movement demanding the creation of a separate Jharkhand State. At first, this movement was dominated by tribal people (adivasis) and called for a separate State for the region's tribal population. From the 1960s onwards, the movement had to broaden its scope as adivasis declined as a proportion of the region's population. Thereafter, support hinged around the grievances created by economic transformation, which united otherwise disparate groups in opposition to exploitative and locally insensitive 'dikus' (outsiders). State sponsored natural resource exploitation and economic development more generally, thus created the 'social pressures that led to the creation of a politically meaningful Jharkhand region and repeated demands for a separate Jharkhand state' (Stuligross, 2001: 133). For many years, these demands were rejected because of the central state's unwillingness to generate a 'domino effect' in other areas of ethno-regional tension (Munda, 1988). During the 1990s, however, the Bhartiya Janata Party (BJP) sought to consolidate electoral support in the region by advocating the Jharkhand cause, and on 15 November 2000 (32 months after the BJP came to power at the centre) Jharkhand became India's 28th State.

Although the Jharkhand movement resists classification as either an ethnic or an environmental movement, it has, at different times, mobilised clear elements of both with frequently violent outcomes. Consequently, it represents an interesting case study with which to examine the relationship between natural resources and ethnic conflict. Given the criticism aimed at the environmental security school's (Homer-Dixon, 1999) simplistic causal linkages between environment and violence and lack of attention to space and place (Peluso and Watts, 2001), this paper will examine the movement from a political ecology perspective: an approach that prioritises geography and focuses on how power relations influence access to and control over environmental resources while recognising the need 'for far-reaching changes to local, regional and global political-economic processes' (Peet and Watts, 1996: 1). 
Although political ecologists have tended to eschew 'theory in favour of empirical analysis' (Bryant and Bailey, 1997: 1), they have sought to avoid the limitations of localised study by situating the findings of micro-scale research in a broader theoretical comparative framework. Political ecology's actor-oriented approach (Long and Long, 1992) has been particularly useful in this regard as it fosters understandings about the interests, characteristics and actions of different types of actors in understanding political-ecological conflicts... (cooperation too) as an outcome of the interaction of different actors pursuing often quite distinctive aims and interests' (Bryant and Bailey, 1997: 23-24). With their sensitivity to the importance of place and willingness to investigate environmental issues at the community level, actor-oriented approaches are ideally placed to examine whether (and to what extent) the sociocultural values associated with environmental resources influence how they are mobilised politically (Stott and Sullivan, 2000). They also seek to enable 'excluded voices' to be heard (Foucault, 1990) as well as to provide an in-depth analysis of differences within communities.

In analytical terms, political ecology 'provides tools for thinking about the conflicts and struggles engendered by the forms of access to and control over resources' (Peluso and Watts, 2001: 25) but is necessarily complex as it embraces issues ranging from gender relations, land rights and local systems of governance to the sociocultural value of environmental resources. Political ecology research into resource conflicts therefore seeks to understand the circumstances in which violence erupts by situating actors within wider environmental and sociopolitical contexts. As the specific circumstances that result in resource conflict are often strongly rooted in local history and social relations, as well as being connected to wider economic and power relations, political ecology's multiscale approach can be very helpful for generating different layers of analysis, starting from a very local level and working upwards to a more regional understanding of the problem (Blaikie and Brookfield, 1987; Peet and Watts, 1996).

In terms of generating solutions to resourcerelated conflicts, however, political ecologists have been better at critiquing the status quo than developing a 'feasible blueprint for an alternative political economy' (Bryant and Bailey, 1997: 4). Nevertheless, there is broad agreement among political ecologists on the need for locally based responses to resource management problems based on 'local-level decision-making by grassroots actors' (Bryant and Bailey, 1997: 5). A classic Indian example of this is Guha's work that deploys the concept of a moral economy of provision to both highlight the inequity of efforts by the state to marginalise 'ecosystem people' (Gadgil and Guha, 1995: 3-4) and generate solutions based around their environmental knowledges and 'natural economy'.

Echoing Guha's account of resource-related struggles in Uttarakhand's 'unquiet woods' (Guha, 1989), conflict in Jharkhand can be portrayed as part of a resource-based battle fought out between the representatives of capital and the defenders of a natural (moral) economy whereby the latter attempted to survive amid the destructive environmental practices of mine owners and timber contractors. As new forest guards appeared to challenge the movement, so did miles of barbed wire. Local people came to see the forests as alien territories and responded accordingly (Corbridge and Jewitt, 1997).

According to Parajuli (1996), adivasi (tribal) politics in Jharkhand has been 'synonymous with the politics of jal (water), jangal (forest) and jamin (land)' (31) as adivasi communities have come into conflict with the state over access to these key natural resources and the uses to which they are put. Parajuli makes explicit linkages between ecological exploitation and ethnic subordination, suggesting that if 'ecological subordination is the content, ethnicity is the form in which it is experienced and expressed' (10, emphasis in original). With respect to Jharkhand, he argues that ecological and ethnic concerns have converged and adivasi 'cosmovisions' have been politicised in an effort to challenge the state's dominant developmentalist vision and reassert traditional systems of environmental knowledge and management.

In recent years, the potential of such 'traditional' community-based environmental management systems has attracted the attention of development policy-makers who recognise that sustainable resource management is closely linked to poverty alleviation (Fisher et al., 1995; 
Kumar et al., 2000; World Bank, 2000; World Bank, unpubl. data, 2001) and that 'the effectiveness of government as a resource manager is improved when it shares power with different user groups' (Kumar, 2004: 232). When thinking about political ecology solutions to resourcerelated conflict, however, it is important not to romanticise 'traditional' systems of communitybased environmental management that supposedly prioritise considerations of social justice and environmental conservation. In this regard, a non-essentialising 'micro political ecology' approach (Neumann and Schroeder, 1995) is valuable for highlighting the inequalities in wealth, ethnicity, knowledge and power (as well as discordant environmental views) that so often characterise supposedly homogenous communities. In-depth actor-oriented understandings of this nature can also be vital in proposing appropriate community-based resource management solutions and employment-generating schemes that work around such inequalities, thus helping to address resource-related grievances at the local level and prevent their escalation (and political mobilisation by elite groups) into violence at a regional scale.

The rest of this paper will focus on conflicts surrounding four natural resources in Jharkhand: land, minerals, forests and agriculture/ water. Reflecting both political ecology's emphasis on local-level responses to resource conflicts and the author's view that the resolution of grassroots-level resource-related grievances may help to prevent their escalation into full blown conflict, the emphasis will be on problem solving from the bottom up.

\section{Livelihood resources: Four arenas of conflict in Jharkhand}

\section{Land}

In the precolonial period, groups of adivasi pioneer settlers (known as bhuinhars in Oraon and khuntkattidars in Mundari) cleared patches of jungle for cultivation (Roy, 1915; Sachidananda, 1970; Imam, 1990). They considered themselves and their descendants to be the rightful owners of the land thus reclaimed: land that could not be transferred to settlers of a different clan without their permission. In around the sixth or seventh century $A D$, the adivasis adopted the Chota Nagpur Raja as their leader and started to pay a fixed tribute to him (Roy, 1946). After 1585, the Chota Nagpur Raja was forced by the Mughal Emperor of Delhi to raise the level of tribute and sent in Hindu rent collectors. This resulted in large-scale land alienation as many rent collectors decided to take adivasi land for themselves as part of their share of the rent (Roy, 1915, 1931, 1932; Corbridge, 1991). This marked a significant turning point in the development of conflict over land.

When British colonial administrators visited Jharkhand, they misunderstood the existing situation of rent collection and made the Chota Nagpur Raja a landlord, seeking to extract from him a sizeable annual tribute. At the same time, landlords from the plains migrated into the region along with moneylenders, traders and their 'armed lackeys' (Parajuli, 1996: 4) who set about plundering Jharkhand's natural resources. In addition, the British made alienable village lands that had traditionally been owned as common property and restricted the rights of local communities both to use forests and to reclaim forest land for cultivation (Roy, 1915).

This resulted in agitation for change. The Kol rebellion of the early 1830 s and the Santhal hul (uprising) of 1855 both focused around the issues of land alienation, the exploitation of adivasis by Hindu moneylenders and merchants and the settlement of tribal lands by 'dikus' or outsiders (Roy, 1946; Hoffman, 1961; Sinha et al., 1969; Sachidananda, 1970). Following the Kol rebellion, the British imposed the 'Wilkensen Rules' that prevented new immigrants from owning land without government permission and conducted a major land survey between 1869 and 1880, which sought to establish a record of rights detailing the location of khuntkattidari and bhuinhari lands. Although the Raj worsened matters by appropriating land that was not obviously 'settled' or owned, it also promulgated the Chota Nagpur Landlord and Tenant Procedure Act that helped to restrict increases in rents and sought to control the alienation of tribal land.

Unfortunately, these measures did not stop migrants from purchasing or stealing tribal land and discontent among adivasis resurfaced, a situation that helped to mobilise an 'idea of violence' over land rights and diku exploitation drawn upon later by activists within the Jhark- 
hand movement. Between 1890 and 1895, the Birsa Rebellion (led by Birsa Munda) gathered momentum in its quest for agrarian reform and an end to British rule (Sachidananda, 1970). Birsa's main aim was to 'create adivasi rule in Jharkhand and restore adivasi lands, forests and commons that were illegally claimed by the colonial government and the dikus' (Parajuli, 1996: 19). The uprising met with a violent response from the British, although the colonial state did go on to pass the Chota Nagpur Tenancy Act of 1908 that curtailed but did not stop the alienation of adivasi land to non-tribals. In particular, tribal land continued to be acquired by the state and private companies for industrial use by virtue of the Land Acquisition Act of 1894 on the grounds that such usage would serve 'a public purpose' (Corbridge, 1991).

A similar pattern continued after independence. Since the 1950s, hundreds of thousands of acres of tribal land have been lost to industrial development and in the 1990s alone, 90000 people were displaced by the Damodar Valley Corporation (Parajuli, 1996). The failure of government pledges to employ 'one family member in the industry that comes to occupy his former home' (Stuligross, 2001: 192), meanwhile, created extra pressure on forests and agricultural land as alternative livelihoods were sought.

Although the initial response to statesponsored land alienation was one of passive consent, 1965-1975 marked a period of struggles for compensation for lands lost to mines, industry, dams and other development projects. From 1975 onwards, such development programmes were greeted with more active resistance and violence. With respect to land 'illegally usurped by landlords and moneylenders' (Stuligross, 2001: 175), meanwhile, the Jharkhand Mukti Morcha party (JMM) encouraged forcible crop cutting by the 'true' owners, thereby mobilising widespread rural support around the issue of land alienation. Between 1973 and 1976, there were 120 violent incidents including 48 of forcible harvesting and looting of crops (Stuligross, 2001). Violent conflict also occurred in connection with land acquired by the state for broader development purposes. On 30 April 1978 at Chandil, police fired at a crowd of adivasis who were protesting about the acquisition of their land by the Subarnarekha Multi-Purpose Project. Three adivasis were killed. In July 1978, meanwhile, N.E. Horo of the Jharkhand Party implemented a phase of 'direct action', in response to the Indian government's refusal to create a separate Jharkhand state, which included the gheraoing (surrounding) of government officials and the destruction of transport links to prevent vital natural resources from leaving Jharkhand.

\section{Minerals}

Despite Jharkhand's characterisation as the 'Ruhr of India', the benefits of its mineral wealth often eluded the region's adivasis who, conversely, bore a disproportionate amount of the costs associated with Jharkhand's economic transformation (Stuligross, 2001). Because of the provisions of the Land Acquisitions Act of 1894, land for mining purposes could be acquired from adivasi communities despite the restrictions of the Chota Nagpur Tenancy Act. A prime example of this was the loss of 100000 acres of tribal land to the Bengal Iron and Steel Company (BISCO) and Tata Iron and Steel Company (TISCO) in Singhbhum District between 1915 and 1925. Compensation amounted to a fraction of the value of the land and sometimes to less than $5 \%$ of the price paid in other parts of Bihar (Corbridge, 1991). The issue of land alienation thus became an important grievance for communities 'undermined' as a result of mineral extraction.

Initially, local communities did at least benefit from employment in the mines and many (permanent and non-permanent) mine labourers 'earned incomes in excess of anything they could have earned in their villages' (Corbridge, 2004: 185). Corbridge notes that in $1921,64.65 \%$ of unskilled coal workers and $57.83 \%$ of skilled workers were classified by the British as 'tribal' or 'semi-aboriginal' and adivasis were similarly well represented in other mining activities at this time. In the 1950s and 1960s, however, new coalfield owners (Marwaris, Bengalis and Gujaratis had largely replaced the British) started to recruit labour from North Bihar. Corbridge links this to the fact that 'dominant political interests of North Bihar put pressure on the mine owners to look "north- 
wards" once they realised that the post colonial state was set to guarantee remunerative wages in the mines' (Corbridge, 1986: 239). As a result, many adivasis were dismissed from the coalfields, and by 1971 , only $2.7 \%$ of Chota Nagpur's male adivasis and $2.65 \%$ of its female adivasis were engaged in mining and quarrying and non-household industry. In 1972, the nationalisation of most of India's coalfields gave the Bihar state government control over Jharkhand's coalfields and resulted in the replacement of 50000 Jharkhandi miners (both tribal and non-tribal) with workers from north Bihar (Stuligross, 2001). Those who did find work in the mining and industrial sectors were frequently paid well below the minimum wage.

Although violent protests against such exploitation and loss of employment were not as widespread as those directed against agricultural land alienation and forest policies, A.K. Roy's wing of the JMM did seek to replicate the success of the JMM's crop cutting activities within the industrial sphere. During the 1970s, a group of Roy's JMM supporters joined with a group of adult education workers to form the Singhbhum General Workers Union that held 'workers educational meetings' to explain to the labourers 'why and how their deteriorating wages and conditions were linked to wider changes and problems within the ownership and organisation of South Bihar's mining industries' (Corbridge, 1986: 314). In conjunction with JMM 'direct action' in the form of gheraoing mine owners and forcing (temporary) increases in mine wages, these activities were successful in radicalising the political consciousness of mine workers in Kolhan.

During the 1980s and 1990s, violence relating to mineral resources was spearheaded by the JMM and the All Jharkhand Students Union that organised regular bandhs and economic blockades, often involving the closing of roads and the blowing up of railway tracks. The main aim behind such actions was to hold the rest of India to ransom by preventing valuable natural resources from leaving the region. Inevitably, such events resulted in violent conflict with a region-wide bandh on 1 January 1989, causing 75 deaths. Even more serious was the JMMsponsored 10-day economic blockade in April 1992, which cost India around Rs. 5 billion. Inevitably, it attracted serious police repression and resulted in the arrest of over 2000 people (Stuligross, 2001).

\section{Forest policy}

Forests are a key livelihood resource for Jharkhand's inhabitants and are also imbued with great sociocultural value for the region's adivasi and sadan (artisan caste) population. As adivasi control over Jharkhand's forests was gradually eroded, threats to forest-based livelihoods resulted in conflict and, at certain points during the 1970s and 1980s, in violence, much of it sponsored by timber contractors and mine owners (Corbridge, 1991; Areeparampil, 1992). Significantly, and reflecting the situation with respect to land and mine struggles, resource shortages have had little to do with much of the forest-based violence that has occurred in Jharkhand. Instead, conflict has been linked much more closely with the implementation of state forest policies that criminalised traditional forest users while allowing corrupt forest officials and contractors to profit from the timber trade and deprive local villagers of their livelihoods. To examine how such conflicts developed and identify turning points in the route towards violence or non-violence, it is important to provide some historical context to forest use and management in Jharkhand.

Although few concrete data actually exist on pre-British forest management in Jharkhand, Kelkar and Nathan suggest that the village community...seems to have been the acknowledged owner of the forest around it in the sense that its use of the forest... was an unhindered right, and did not involve any payment to or permission of a superior' (Kelkar and Nathan, 1991: 121). All this changed in 1878 when the Indian Forest Act empowered the British colonial state to 'declare any land covered with trees, brushwood or jungle as government forest by notification' (Ghate, 1992: 33). After 1894, India's forests were divided into four categories: (i) Reserved Forests; (ii) Protected Forests; (iii) Private Forests; and (iv) Village Forests. Of these, only Village Forests were available for unrestricted use by local people and Reserved Forests were out of bounds except for the collection of certain non-timber forest products (NTFPs) such as fruit. Many villagers had to cope with the sudden loss of 
forest-based religious sites and severe disruption to subsistence production. The British Forest Department's commitment to the use of force to punish 'forest offences', meanwhile, meant that the criminalisation of local forest users emerged as a counterpart to state monopoly control of Reserved Forests.

In Jharkhand, the Chota Nagpur Tenancy Act retained unrestricted forest rights only within the Munda khuntkattidari system although the nineteenth century Kol, Santhal and Munda uprisings had helped to preserve regulated user rights for many forests in Ranchi District (Kelkar and Nathan, 1991: 126). Elsewhere, 'diku Raj' prevailed in the Reserved Forests while control over most non-Reserved Forests was placed in the hands of local zamindars.

The postcolonial period has been characterised by a strong degree of continuity with British systems of forest management (Jewitt, 1995a,b). In theory, local needs were supposed to be met first and any surplus was to be sold to contractors at auction or to non-right holders at concessionary rates. In practice, the contractors often cut far more of the forest than they had paid for in order to sell off the surplus wood to charcoal-makers for their own profit.

According to Singh, 'if the natural resources of rural and tribal people are to be usurped and no alternative made available to them, the courses of action for such people are few: they either steal, die of poverty, revolt or are forced to migrate' (Singh, 1986: 5). These responses were typical in Jharkhand where many villagers resorted to 'everyday forms of peasant resistance' (Scott, 1985) such as the illegal collection of forest products as a statement of their subsistence rights. Poor harvests in the late 1970s set off a trend of seasonal outmigration that increased as forests declined still further.

Throughout the region, growing resentment about restrictions on forest usufruct sparked off increasing hostility towards the Forest Department, often accompanied by a vicious cycle of illegal fellings followed by intra-village conflict over who received punishments for 'forest crimes' and who did not (Jewitt, 2002). The livelihoods of many rural Jharkhandis were also affected by the nationalisation of the kendu leaves and sal (Shorea robusta) seeds trade in 1973 and 1976 followed by the government's takeover of all trade in minor forest produce (MFP) in 1978 (Areeparampil, 1992). These changes played into the hands of outside timber contractors by discriminating against local collectors in favour of non-local consumers. Also in 1975, the Bihar Forest Development Corporation (FDC) was formed and 192000 hectares were leased to the FDC for clear-felling and replanting with teak and eucalyptus. In the late 1970s, antagonism between local people and the Bihar Forest Department came to a head as attempts to assert traditional forest rights and contest MFP nationalisation were greeted with increasingly repressive responses from the state.

Father Matthew Areeparampil describes how much of the forest-related violence took place in Singbhum District following the start of the jungle katai andolan (forest felling movement) in 1978. During the andolan (movement), adivasi protestors were involved in gheraoing forest officials (demanding that the FDC's work be stopped) and felling trees in attempts to reclaim ancestral land that had been taken by the Forest Department. The state's response to such activities was one of repression and a key turning point occurred in Simdega on 4 August 1978 when police fired at a crowd of adivasis (who were protesting about the takeover of MFP trade) and killed one person. As Areeparampil documents, this was by no means an isolated incident but state repression became more brutal as the jungle katai andolan gathered momentum.

Significantly, these events coincided with a more militant phase of the Jharkhand movement that focused on the political mobilisation of local-scale resource-related grievances. A key actor in this regard was Shibu Soren of the JMM who encouraged his followers to challenge commercial forest exploitation and fight for their rights regarding access to forests (Corbridge, 1986, 1991; Devalle, 1992). Also during 1978, the Sadar subdivision of Singhbum District 'witnessed the outbreak of a well-organised and formidable andolan known as the "Tree War" started by the adivasis of this area' (Areeparampil, 1992: 144). This andolan centred on the old Kolhan Government Estate that had been governed by the British as a special reserve for the dominant Ho tribe according to Ho rules. Unlike the tree protec- 
tion movements of Uttarakhand (Chipko), the Singhbhum andolan pursued illegal tree fellings to register local discontent against the poverty and hunger that many people had been reduced to, and which the andolan's leaders attributed to state forestry and employment policies.

Significantly, much of the violence associated with Jharkhand's Tree Wars was perpetrated by timber contractors and mine owners (and their supporters in the state police) rather than by participants of the andolan. Between 1982 and 1985, police reports in Singhbhum acknowledged 19 instances when the police fired on demonstrators, killing 36 adivasis (Stuligross, 2001). A prime example of such a case is the infamous 'Gua incident' that followed the arrest of 4100 local people for 'illegally cutting trees'. On 8 September 1980, the JMM organised a public meeting at Gua aerodrome to protest against 'state employment policies, state terror, and state forestry policies' (Corbridge, 1995: 5). After a short meeting, the crowd started to disperse and the Bihar Military Police (BMP) caused a scuffle to break out by surging forward to arrest the leaders. Fifty-nine rounds were fired by the BMP and three policemen and eight marchers were killed. A further nine wounded adivasis were surrounded, assaulted and then shot dead by injured policemen at the hospital when they arrived for treatment. Immediately after this incident, the police let loose a reign of terror during which 'thousands of innocent adivasis were dragged out of trains, buses, etc. or picked up from weekly haats [markets], courts or their places of work and put in prison. Villages were raided and women raped and beaten up' (Areeparampil, 1992: 166).

\section{Agriculture and water}

Although many of the grievances relating to the alienation of agricultural land have been dealt with earlier, some background on the challenging nature of agricultural production in Jharkhand is helpful for understanding why violence over state forestry, mine/industrial employment and development policies came to a head in the late 1970s. Because of Jharkhand's undulating and rocky landscape, only $27 \%$ of the region's land is actually cultivable and opportunities for large-scale irrigation are few. Population growth coupled with increasing restrictions on the gath- ering of forest products forced many households to diversify their economic activities.

A key actor on the agricultural scene from the early 1970s was Shibu Soren, who was active in mobilising long-standing grievances over land alienation among peasants in Tundi Block. He succeeded in directing a peasant mass movement aimed at forcible paddy harvesting and appealing to the Santal tribe's 'long tradition of "direct action", Soren led groups of armed tribals up to 1000 strong in campaigns for land restoration conducted in broad daylight' (Corbridge, 1986: 68).

An important turning point for the rest of Jharkhand was the bad harvests of 1978-1982, which put existing household survival strategies under severe strain and forced many villagers to undertake seasonal work in the brickfields of Uttar Pradesh and West Bengal. The most effective means of intensification - irrigation remains limited in many parts of Jharkhand to small-scale developments linked to streams, tanks and wells. By 1981, only $4.53 \%$ of Ranchi District's gross cultivated area was irrigated thus preventing large-scale agricultural intensification (and associated employment). Increasing numbers of landless labourers were therefore forced to look (often unsuccessfully) elsewhere for jobs, notably to the mines. Resentment over the Bihar government's funding of irrigation schemes in the plains but not in Jharkhand, meanwhile, heightened discontent about the exploitation of Jharkhand by North Bihar. At the same time, the loss of agricultural production as a result of industrial pollution fuelled longstanding resentments about land alienation and the loss of good agricultural land to industrial development (Stuligross, 2001).

This mass of local grievances was mobilised into direct action on a number of occasions after 1975, in the form JMM-organised forcible crop cutting plus Machua Gangarai's tree felling campaigns, which involved 67 villages in attempts to reclaim land for cultivation. Gangarai's appeal was to the traditional right of settler families to carve agricultural plots from the forests (Corbridge and Jewitt, 1997). Actual violence relating to agricultural land was associated mainly with the broader Tree War and was, as noted earlier, promulgated more often by the state than by the Jharkhand movement itself. 


\section{The importance of political ecology for analysing resource conflicts}

As the aforementioned examples indicate, resources in Jharkhand have played an important role in generating violent conflict, but the causal linkages are far from straightforward: not least because the Jharkhand movement has played different political cards at different times in its history, depending on what would best support its case for a separate state. Seeking to understand the Jharkhand movement as an ethnic movement is fraught with problems as the region is far from ethnically homogenous and in recognition of this, the movement had to shift away from ethnicity towards regionalism as a mobilising factor over time. Conflict rooted in resource claims, on the other hand, has been important throughout the movement's history. The nineteenth-century tribal uprisings, for example, had a strong resource-related dimension (land alienation) while the Jharkhand movement succeeded in uniting and mobilising the region's adivasis around issues relating to the impacts of economic transformation on vital natural resources (notably land, forests and water) and the erosion of traditional livelihoods. A particular source of resentment hinged around the fact that the benefits derived from Jharkhand's mineral wealth eluded a large proportion of adivasis, while they suffered disproportionately from the socioenvironmental costs of mining.

While analysing the progress of the Jharkhand movement is helpful for comprehending the causes of violent conflict at a regional scale, it is less helpful for identifying particular flashpoints that set smaller-scale conflicts in motion. To understand why these may or may not result in violence, and how such localised flashpoints might be prevented from escalating into more widespread violence, it is important to have detailed local understandings of resource conflicts to complement the regional context. Micro-level political ecology approaches are particularly valuable in this regard as their community-level emphases on unequal resource access and socioeconomic differentiation help to reveal intra-village and inter-gender conflicts that more homogenising ethnic analyses would miss (Neumann and Schroeder, 1995; Rocheleau et al., 1996). A brief comparison of small-scale resource conflicts in two adivasidominated (Oraon) villages of Ranchi District, studied by Jewitt (1995b, 2000, 2002), should illustrate this well.

The first village, Jamtoli, is relatively small, fairly homogenous in ethnic and socioeconomic terms and benefits from a popular and charismatic leader, Simon Oraon. Prior to independence, the village had a long tradition of forest management, but this was disrupted when Jamtoli forest came under state control and was subjected to commercial timber exploitation coupled with illegal felling by contractors. Foreseeing the long-term difficulties of excessive forest exploitation, Simon Oraon gathered together a large group of villagers. Carrying bows and arrows, the villagers challenged the contractors and confiscated the cut timber. Although this particular incident did not result in bloodshed, villagers' willingness to fight for their rights to Jamtoli forest was clearly apparent and could easily have escalated into violence under different circumstances. Soon after this incident, Simon established a formal system of forest protection and management that is still in existence today. His success stemmed largely from the high level of respect that most villagers have for him: not least because of his efforts to improve villagers' livelihoods by developing irrigation systems that allow most households to meet their subsistence needs.

The second village, Ambatoli, is larger, more spatially dispersed (with seven hamlets) and more ethnically and socioeconomically homogenous. Ambatoli forest, although extensive, is extremely degraded, containing only a handful of large trees. Unlike Jamtoli, Ambatoli had no strong leader to help villagers mobilise support against illegal timber felling by forest contractors. As a result, most villagers accepted their rightful share of the timber harvest from the contractors when they got it. When they did not, they cut the forest themselves. Fuelwood selling started in the 1970s and provides an important source of income for landless villagers and although many people in Ambatoli are interested in forest protection, the establishment of sustained unity between the seven hamlets has proved very difficult. Two of the hamlets are dominated by virtually landless sadans who rely heavily on selling fuelwood for their income. Another hamlet has a large proportion of Hindu 
Backward Caste households who support forest protection in principle, but feel that many adivasi households spend too much time inebriated to undertake successful forest protection: a reasonable point given that numerous village meetings have ended in drunken brawls. Cross-cutting these ethnic barriers are significant inter-household sociocultural variations that influence the extent to which villagers depend on forest resources for their livelihoods (Corbridge and Jewitt, 1997).

Another layer of potential conflict surrounds the issue of gender and in this regard, feminist political ecology approaches can be very enlightening (Rocheleau et al., 1996). While most village men are aware of how to cut trees in a way that stimulates forest regeneration through coppice growth, few women seem to have this knowledge. Consequently, men blame women for causing forest decline through fuelwood collection and women blame men for cutting all the big trees down. Given that resource-related decision-making in the region is strongly male-dominated, however, these different perspectives are rarely discussed in public and men fail to benefit from women's more detailed knowledge of the village's fuelwood resources (Jewitt, 2000, 2002).

To complicate matters still further, there are important intra-gender variations with respect to forest use that sometimes result in conflict. Ambatoli's wealthier Backward Caste households see themselves as superior to the adivasis and demonstrate this by encouraging a loose form of purdah and 'buying women out' of forest-based gathering and field-based agriculture work - usually by hiring casual labourers to do such tasks. Within households, too, gender bargaining over task allocation can be quite intense with younger women, especially daughters-in-law, being allocated the most tiresome jobs.

One consequence of these intra-village variations in forest use is that different villagers have quite different opinions on what the forest should be used for and whether it should be protected: opinions that have often ended in conflict and the abandonment of efforts to establish village-wide forest protection. And although this type of intra-village conflict over resource use and management is unlikely to result in major cases of violence, these case studies nevertheless highlight the importance of micro-political ecology in revealing what factors generate local disagreement and how they can be overcome to prevent grievances from developing and conflict from escalating. A micro-political ecology approach is also ideally placed to investigate an important aspect of natural resources overlooked by most theoretical analyses of resource conflict: namely their sociocultural importance. Pramod Parajuli (1996), for example, argues that adivasi agroecological cosmovisions have played a central role in the Jharkhand movement's resistance to state forestry policy and industrial development, suggesting that 'a monocultured forest is not acceptable to adivasis. Forests must be diverse in form and function' (18). This explains why in the early 1980s, 'in a gesture of protest against monocultured forests, $\mathrm{Ho}$ and Santal adivasis of Kolhan pulled out sagwan (teak) saplings and replanted sal saplings' (Parajuli, 1996: 18). With reference to Jharkhandi mobilisation around land alienation, meanwhile, he argues that for adivasis, 'alienation from the land means the loss of their cultural identity, and political autonomy - the very basis of their survival' (Parajuli, 1996: 11). Consequently, Parajuli argues that protecting these areas and also sacred groves 'from the axes of timber contractors or from submersion by big mines and/or big dams [became] one of the main struggles in Jharkhand' (Parajuli, 1996: 25).

\section{Solutions}

When thinking about solutions from a political ecology perspective, however, the sociocultural importance of environmental resources should not blind us to the dangers of romanticising local agro-ecological knowledges and environmental protection strategies. Local knowledges are often not as complete as some moral economists make out and it should be acknowledged that many traditional Jharkhandi systems of forest protection and management have long since been eroded along with the tribal political institutions that organised them. When considering community-based resource management institutions as a means of simultaneously promoting forest growth and reducing resourcebased conflicts between users, therefore, micropolitical ecology approaches can be helpful in 
challenging the grotesquely romanticised peasant/tribal/female essentialism that has so often accompanied accounts of India's nonstate forest users (Corbridge and Jewitt, 1997; Jewitt, 2000, 2002).

Gadgil and Guha (1995), for example, commend an institutional ecology approach to India's resource conflicts that embraces the wisdom of India's 'ecosystem people'. But Guha is no simple romantic. His later work with Gadgil reveals a disenchantment with the idea of designing forest policies on the basis of a mythologised past system of harmonious forest management based on the 'feminine principle' (Shiva, 1988). Instead, Guha accepts that new institutional frameworks will have to be built to allow indigenous agro-ecological knowledges and practices to flourish in a new moral economy framework. But his main concern is with a future moral economy of forestmanagement-by-forest-citizens because global conditions have closed off other sustainable options to ex-colonial countries such as India (Corbridge and Jewitt, 1997). He is also keen to highlight the inequity, illegality and unsustainability of state attempts to criminalise/ marginalise local forest users in the name of state monopoly rights in land and scientific forestry. In doing so, he echoes the voices of many Jharkhand activists by showing us who are the criminals in the bigger picture.

\section{Community-based resource management}

Significantly, there has been an important shift in the way that India's forests are being managed in the wake of Chipko and Jharkhand's Tree Wars. The potential of communitybased resource management systems for promoting environmental protection and reducing conflict between stakeholders has received considerable attention since the mid-1980s (Fernandes and Kulkarni, 1983; Mehrotra and Kishore, 1990; Kant et al., 1991). In the late 1980s, the Government of India, under pressure from environmentalists, 'forest intellectuals' (such as Guha) and funding agencies (such as the World Bank), shifted away from an emphasis on commercial forest management. India's 1988 National Forest Policy focused on the need to conserve and regenerate degraded land (Shah, 1995) and emphasised local participa- tion at all stages, while from 1990, States were encouraged to manage degraded forests in conjunction with local people under Joint Forest Management (JFM) programmes.

Using Guha's approach as a starting point, the following sections will analyse the potential of community-oriented approaches to reverse the top-down and frequently antagonistic forms of forest management that characterised Jharkhand from 1865 to 1990 . They will also offer suggestions on how such approaches, in combination with local-, regional- and nationalscale policy-making, could reduce resourcebased conflicts in future, by addressing locallevel grievances before they can escalate into large-scale violence. Because of both the author's own expertise in this area and the potential of participatory forest programmes to address wider employment and village development issues, the primary focus will be on forestry.

\section{Common pool, participatory and joint resource management}

Much painstaking research on the conditions most likely to encourage the establishment and maintenance of common pool resource management systems has been conducted by Elinor Ostrom $(1990,1999)$. Key factors that she identifies include the importance of the resource to its users, a recent history of community resource management, a belief that resource management benefits will exceed the institutional costs, a shared image of the resource and a strong sociocultural attachment to it. When adjusted to take account of the locally specific characteristics of a resource and its users, such checklists are valuable tools for governments, nongovernmental organisations (NGOs) and development donors to use when attempting to stimulate the development of new institutions among interested users.

With regard to participatory or joint resource management systems, additional insights are provided by Shepherd's $(1993 a, b)$ models that link the extent of community-based resource management to population density, land use and proximity to urban areas. Shepherd also indicates villagers' main land use options for different area types and suggests where interventions such as JFM are most likely to succeed. 
In essence, these models seek to avoid conflicts over resources by encouraging the funding of individually oriented income and employmentgenerating schemes in villages where community resource management is unlikely to succeed (Jewitt, 2002). Significantly, Shepherd predicts that the potential of JFM is limited to fairly remote villages with extensive land use and lots of common pool resources. Nevertheless, she does suggest that it may be possible to extend the boundaries of likely success to villages with a high level of interest in JFM or a strong sociocultural attachment to forests, especially if 'helpful state intervention' is available. It is perhaps useful at this point to turn to joint and participatory forest management in Jharkhand and investigate the extent to which they have been (or are likely to be) effective as a means of both addressing forest-related grievances and preventing future conflict over forest resources.

The format and workings of JFM in Jharkhand are shaped largely by the way in which the scheme was set up in the State of Bihar in 1990 (Jewitt, 1995b) although the Government of Jharkhand extended the reach of JFM from degraded Protected Forests to all types of forest in 2001. Under this programme, JFM committee members are responsible for day-to-day forest protection and have free access to subsistence poles, fuelwood and NTFPs as well as obtaining $90 \%$ of net revenues from commercial timber and bamboo products. To date, 1379 JFM committees have been established, 430463 hectares are currently being protected under JFM and forest cover in Jharkhand has increased by $1071 \mathrm{~km}^{2}$ since the State's creation in November 2000 (Government of Jharkhand, 2007).

On paper at least, JFM in Jharkhand appears to meet the requirements implicit in Guha's model of a sustainable/empowering moral economy of forest management while at the same time, ameliorating villagers' long-standing disgruntlement over resource (mis)use by the Forest Department. But to maximise the success of JFM and other participatory forest management (PFM) initiatives, it is essential to steer clear of 'green orientalist' romanticisations of local forest users (Lohmann, 1993) by keeping a firm handle on local development priorities and existing constraints to their attainment.
For a start, the spatial dynamics of trust and moral economy are by no means secure and a sense of belonging, not to mention empowerment and active citizenship, is not a primordial feature of tribal communities, but needs to be carefully fostered. As Gujit and Kaul Shah point out, the tendency to view 'all local people as insiders clearly perpetuates a simplification of intra-communal differences, and hides the reality of high levels of participation by some groups and none by others' (Gujit and Kaul Shah, 1998: 10).

In many JFM villages in Jharkhand, the initiative has been taken by a number of powerful/ wealthy families while many poorer villagers have followed at a distance, simply accepting that their voices count for very little. Kumar's (2004) field research in Jharkhand found many JFM committees to be dominated by village elites who put a premium on sal pole extraction for agricultural implements and house building: a situation that reduced opportunities for the opening up of the canopy to promote the growth of NTFPs that are more important to the poor. Other studies have shown how resourcepoor villagers often participate in JFM only tangentially and sometimes as 'forced' forest guards (Corbridge and Jewitt, 1997; Kumar, 2004); a major component of this group being women who face the additional drudgery of having to travel further to collect fuelwood when forest protection commences. To a large extent, their problems go unacknowledged because of wider social norms that discourage their participation in resource management institutions, despite efforts by JFM to include them (Agarwal, 1997; Jewitt, 2000).

Another point of weakness with JFM in Jharkhand is that it attempts to deal with forestry and environmental concerns largely in their own terms. Forests are said to be degrading because of conflicts over forest use, so the answer is to change those patterns of usage. But Jharkhand's forests are also in decline because of population pressures and because forest-dependent villagers have few other assets besides the forests and promises of work elsewhere. JFM does not change this in the short run. It promises committee members plenty in the years ahead, but little at the beginning (save for some saplings) to improve their livelihoods (Kumar, 2004). Indeed, by forcing participants to calculate and 
act over extended spatial and temporal horizons, JFM presents significant difficulties for resource-poor households. And while many may indicate some support for delayed gratification when first approached, brute realities make such actions difficult in practice, especially when forest protection activities are timeconsuming and/or open to free riding by others (Corbridge and Jewitt, 1997). Consequently, many Jharkhandi activists criticise JFM for its failure to alleviate many existing grievances over access to forest wealth and also because it falls short of the Jharkhand Jangal Bachao Andolan's (Save the Forest Movement) demand that the Jharkhand government should recognise adivasis 'as the only owners of [our] ancestral forest' (Debbarma, n.d.).

It should not be forgotten, however, that in contrast to pre-1990 forest policy, JFM represents an important step forward. In addition to increasing villagers' access to state forests, it has brought improvements in villager-Forest Department relationships and has also coincided with a reduction in forest-related violence. At the same time, critiques of JFM have helped to spawn a range of alternative PFM initiatives that seek to address JFM's failings while building on its strengths. Perhaps the bestknown example of this is the World Bank's Participatory Forest Management Project (PFMP) in Jharkhand, which was set up in 2004 and seeks to 'balance natural resources management concerns with poverty reduction and improved livelihoods' (Kvam and Nordang, 2005: 11). To enable the PFMP to work around sources of likely conflict (at the intra- and extra-village level) and build upon existing sociocultural priorities and development aspirations, the World Bank has undertaken detailed participatory appraisal with stakeholders in conjunction with local development organisations.

In an attempt to achieve forest conservation alongside the 'creation of livelihood opportunities for forest fringe communities' (Kvam and Nordang, 2005: 30), the PFMP has undertaken in-depth social assessments 'focusing on social diversity and gender dynamics and on sociocultural, political, and historical factors' (17-18). It has also acknowledged the region's long history of 'tension and mutual distrust among different stakeholder groups - and particularly between the Forest Department and tribal communities'
(Kvam and Nordang, 2005: 23). To ameliorate such tension, the World Bank advocates more flexible forest management partnerships to 'enable forest-based communities to have ownership of and management control over their natural resources' (Kvam and Nordang, 2005: 29) and suggests that where khuntkatti and similar tribal governance systems are still working, PFM should work in conjunction with them. At the same time, the PFMP has attempted to analyse the divergent concerns and interests of different stakeholders and make arrangements for 'poor and vulnerable groups to participate in a meaningful way' (Kvam and Nordang, 2005: 11). In particular, the project has sought to promote income- and asset-generating activities that produce a quick return for participating villagers. Activities identified by stakeholders for support by the project include food processing, marketing of herbal medicines, dairying, pig and poultry breeding, lift irrigation, community biogas and electrification as well as capacity building in relation to forest micro-planning, resource management, accounting, conflict management and community organisation (Kvam and Nordang, 2005: 30-31).

If this and similar schemes were to be implemented more widely, PFM could work more effectively for the poor while at the same time helping to reduce the likelihood of local resource conflicts developing into more serious grievances that can be mobilised as part of a wider (and more violent) political movement. At the same time, JFM could increase its potential to reduce villager-Forest Department tensions and create livelihood (as well as environmental) benefits if the scheme was applied in a more sensitive manner and adopted some of the techniques used by the PFMP.

In particular, JFM in Jharkhand needs to become more flexible to allow both participatory and more autonomous forms of community-based forest management to coexist with it. To maximise JFM's chances of success (and minimise the risk of conflict associated with failure), factors such as the sociocultural and subsistence-related importance of forests to local people and their history of (or interest in) community-forest management (Shepherd, 1993a,b; Ostrom, 1999) need to be taken into consideration when identifying potential project villages. 
When suitable communities have been identified, PFM/JFM must ensure that villagers' support is sustained by providing immediate additional assets such as employment, irrigation, alternative energy or cheap loans coupled with training programmes to promote the setting up of small businesses. Forest-based incomegenerating work (such as planting, thinning and infrastructural development) and the promotion of fast-growing NTFPs (such as bamboo and other grasses) can be of particular value to resource poor villagers in the early years of PFM/JFM. In the longer term (and on a wider scale), much more can be done in conjunction with NGOs to strengthen village institutions, promote greater community self-reliance, and increase poor people's access to employment, skills, financial services, technology, markets, land and other natural resources.

To maximise the opportunities for women to participate, meanwhile, Forest Department and donor agency staff need to acquire detailed, locally specific understandings of genderresource relations and more female facilitators and forest officers need to be employed and given attractive financial incentives to work at the village level. Increased funding for longterm village-based work is especially valuable in Jharkhand where prejudice against adivasi customs has long been pronounced and important linkages between the technical and sociocultural aspects of local resource management systems have been at best ignored by diku development initiatives. In the past, such cultural alienation has played an important role in creating grievances and promoting violence, so in future forest management initiatives, local people's 'culture and knowledge, especially as they relate to the management of forests and other natural resources, need to be respected, protected, and revitalized' (Kvam and Nordang, 2005: 11).

\section{Conclusions}

For joint and participatory resource management initiatives to be successful in protecting local environments and preventing wider forms of resource-based conflict, they must address a strongly felt development need and be funded and planned to give long-term support to their target communities. The het- erogeneity of interests that characterise most local communities undermines simplistic assumptions about their supposedly innate effectiveness as natural resource managers. To promote realistic rather than romanticised impressions of local people's development priorities and constraints, therefore, it is crucial to encourage flexible, locally oriented development projects that can investigate and work around existing micro-political ecologies, power structures and sociocultural norms. But seeking to create real empowerment opportunities for resource poor villagers is no easy task as 'empowerment is a relative concept, it cannot take place without the relative disempowerment of another group, and power is usually not given up voluntarily, rather it must be taken' (Crawley, 1998: 31).

In this regard, responsibility for the success of participatory resource management lies less heavily with local villagers than it does with the ability of governments, NGOs or other development agencies to supply the necessary 'helpful intervention' (Shepherd, 1993a,b) to simultaneously promote resource protection, reduce conflict between users and address longstanding resource-related grievances. But such intervention is not sufficient just at the local scale. It needs to be supported at the regional scale, by the Jharkhand government, and also at the national scale in the form of rethinking the relationship between development and conservation goals (Fisher et al., 1995). With respect to forests, for example, the Jharkhand Minister of Forests needs to create more open, competitive markets in MFP, employ more female forest officers and extend eligibility for JFM. At the national level, the central government needs to intervene in timber markets (in favour of smaller diameter pieces) and move away from Indiawide JFM prescriptions towards more locally oriented plans that benefit non-elite villagers through their focus on NTFPs rather than pole production (Kumar, 2004).

In reality, of course, many difficulties stand in the way of these proposed solutions. Far from bringing political stability to the region, the Jharkhand State government has been notoriously corrupt and unstable. In its first three years, Jharkhand had two chief ministers, four chief secretaries and nearly a dozen bureaucratic reshuffles and found it very difficult to 
'rise above the diverse pulls of coalition politics' (The Telegraph, Calcutta, 17 November 2003). And instead of seeking to ameliorate the region's long-standing resource-related conflicts, it has favoured industrial development at the expense of local subsistence and land claims and used tactics similar to those used by the Bihar government in response to protests using 'direct action' tactics (Corbridge et al., 2004). When the Marandi Government announced its intention to speed up the Koel Karo hydroelectricity project in January 2001, for example, a group of adivasis promptly organised a road blockade and a gherao in Topkara and were fired upon by the police who killed eight protestors and injured several more. In January 2003, meanwhile, police fired on tribals who were making land-related demands and protesting for the withdrawal of false cases at Markachcho thana in Koderma. In terms of finding solutions to these more intractable problems of political instability and corruption, political ecologists have much to learn from political science.

\section{References}

Agarwal, B. (1997) Environmental action, gender equity and women's participation, Development and Change 28(1): 1-44.

Areeparampil, M. (1992) Forest andolan in Singhbhum, in S. Narayan (ed.), Jharkhand movement: origin and evolution, pp. 144-118. New Delhi: Inter-India.

Blaikie, P. and H.C. Brookfield (eds.) (1987) Land degradation and society. London: Methuen.

Bryant, R.L. and S. Bailey (1997) Third world political ecology. London: Routledge.

Corbridge, S. (1986) State tribe and religion: Policy and politics in India's Jharkhand. 1900-1980. PhD Dissertation, University of Cambridge.

Corbridge, S. (2004) Competing inequalities: The scheduled tribes and the reservations system in India's Jharkhand, in S. Corbridge, S. Jewitt and S. Kumar (eds.), Jharkhand. Environment, development and ethnicity, pp. 175-202. New Delhi: Oxford University Press.

Corbridge, S. and S. Jewitt (1997) From forest struggles to forest citizens? Joint Forest Management in the unquiet woods of India's Jharkhand, Environment and Planning A 29(12): 2145-2164.

Corbridge, S., S. Jewitt and S. Kumar (2004) Jharkhand. Environment, development and ethnicity. New Delhi: Oxford University Press.

Corbridge, S.E. (1991) Ousting Singbonga: The struggle for India's Jharkhand, in C. Dixon and M.J. Heffernan (eds.), Colonialism and development in the contemporary world, pp. 153-182. London: Mansell.
Corbridge, S.E. (1995) Forest struggles and forest protection in tribal Bihar, India. Public Lecture: Department of Geography, University of Colorado, Boulder, April, 1995.

Crawley, H. (1998) Living up to the empowerment claim? The potential of PRA, in I. Gujit and M. Kaul Shah (eds.), The myth of community. Gender issues in participatory development, pp. 24-34. London: Intermediate Technology Publications.

Debbarma, S. (n.d.) An assessment of the implementation of the Indian government's international commitments on traditional forest-related knowledge from the perspective of indigenous peoples. Retrieved 25 May 2007, from Website: http://www.international-alliance.org/ documents/india_eng_full.doc

Devalle, S.B.C. (1992) Discourses of ethnicity. Culture and protest in Jharkhand. New Delh: Sage.

Fernandes, W. and S. Kulkarni (eds.) (1983) Towards a new forest policy. Peoples' rights and environmental needs. New Delhi: Indian Social Institute.

Fisher, R.J., S. Maginnis, W.J. Jackson, E. Barrow and S. Jeanrenaud (1995) Poverty and conservation. Landscapes, people and power. IUCN Forest Conservation Program. Cambridge: IUCN.

Foucault, M. (1990) The archaeology of knowledge. London: Routledge.

Gadgil, M. and R. Guha (1995) Ecology and equity. The use and abuse of nature in contemporary India. London: Routledge.

Ghate, R.S. (1992) Forest policy and tribal development. A study of Maharashtra. New Delhi: Concept Publishing Company.

Government of Jharkhand (2007) Achievements. Retrieved 25 May 2007, from Government of Jharkhand Website: http://www.jharkhandonline.gov.in/depts/ fores/Fores_Achievements2.asp

Guha, R. (1989) The unquiet woods. Ecological change and peasant resistance in the Himalaya. Delhi: Oxford University Press.

Gujit, I. and M. Kaul Shah (1998) Waking up to power, conflict and process, in I. Gujit and M. Kaul Shah (eds.), The Myth of community. Gender issues in participatory development, pp. 1-23. London: Intermediate Technology Publications.

Hoffman, J.S.J. (1961) Principles of succession and inheritance among the Mundas, Man in India 41(4): 324338.

Homer-Dixon, T. (1999) Environment, scarcity and violence. Princeton, New Jersey: Princeton University Press.

Imam, B. (1990) Ecological background of Chota Nagpur Its imbalance and tribal communities, Man in India 70(3): 267-277.

Jewitt, S. (1995a) Europe's others? Forestry policy and practices in colonial and post-colonial India, Environment and Planning D: Society and Space 13(1): 6790.

Jewitt, S. (1995b) Voluntary and 'official' forest protection committees in Bihar: Solutions to India's deforestation? Journal of Biogeography 22(6): 1003-1021.

Jewitt, S. (2000) Mothering Earth? Gender and environmental protection in the Jharkhand, India, Journal of Peasant Studies 27(2): 94-131. 
Jewitt, S. (2002) Environment, knowledge and gender: Local development in India's Jharkhand. Aldershot: Ashgate Publishing Company (SOAS Development Geography Series).

Kant, S., N.M. Singh and K.K. Singh (1991) Community based forest management systems (case studies from Orissa). New Delhi: Indian Institute of Forest Management, Bhopal, Swedish International Development Agency, New Delhi and ISO/Swedforest.

Kelkar, G. and D. Nathan (1991) Gender and tribe. Women, land and forests in Jharkhand. New Delhi: Kali for Women.

Kumar, N., N.C. Saxena, Y. Alagh and K. Mitra (2000) India: Alleviating poverty through forest development, country case study. Operations Evaluation Department. Washington, DC: World Bank.

Kumar, S. (2004) Does 'participation' in common pool resource management help the poor? A social costbenefit analysis of Joint Forest Management in Jharkhand, India, in S. Corbridge, S. Jewitt and S. Kumar (eds.), Environment, development and ethnicity, pp. 232-263. New Delhi: Oxford University Press.

Kvam, R. and H. Nordang (2005) The Jharkhand Participatory Forest Management Project. Social assessment for inclusion, cohesion, and accountability. Government of Jharkhand and the World Bank Social Development Department Training Workshop on Social Assessment, Jharkhand, India. 3-9 February 2004. Washington, DC: World Bank.

Lohmann, L. (1993) Green Orientalism, The Ecologist 23(6): 34-38.

Long, N. and A. Long (eds.) (1992) Battlefields of knowledge. The interlocking of theory and practice in social research and development. London: Routledge.

Mehrotra, S. and C. Kishore (1990) A study of voluntary forest protection in Chotanagpur, Bihar. New Delhi: ISO/Swedforest, Indian Institute of Forest Management, Bhopal.

Munda, R.D. (1988) The Jharkhand movement. Retrospect and prospect, Social Change 18(2): 28-42.

Neumann, R.P. and R.A. Schroeder (eds.) (1995) Manifest ecological destinies, special issue, Antipode 27(44): 321-428.

Ostrom, E. (1990) Governing the commons. The evolution of institutions for collective action. Cambridge: Cambridge University Press.

Ostrom, E. (1999) Self-governance and forest resources. Occasional Paper No. 20. Bogor: Center for International Forestry Research.

Parajuli, P. (1996) No nature apart: adivasi cosmovision and ecological discourses in Jharkhand, India. Paper presented during the '2nd conference on the reconstruction of Jharkhand', August 1996, Cambridge, UK.
Peet, R. and M. Watts (1996) Liberation ecology: Development, sustainability and environment in an age of market triumphalism, in R. Peet and M. Watts (eds.), Liberation ecologies: Environment, development, social movements, pp. 1-45. London: Routledge.

Peluso, N. and M. Watts (2001) Violent environments, in N. Peluso and M. Watts (eds.), Violent environments, pp. 3-38. Ithaca, New York: Cornell University Press.

Rocheleau, D., B. Thomas-Slayter and E. Wangari (eds.) (1996) Feminist political ecology: Global issues and local experiences. London: Routledge.

Roy, S.C. (1915) The Oraons of Chota Nagpur: Their history, economic life and social organisation. Ranchi: Man in India Office.

Roy, S.C. (1931) The effects on the aborigines of Chota Nagpur of their contact with Western civilisation, Man in India 62(1): 65-100.

Roy, S.C. (1932) The study of folk lore and tradition in India, Man in India 63(1): 85-112.

Roy, S.C. (1946) The aborigines of Chota Nagpur. Their proper status in the reformed constitution of India, Man in India 26(2): 120-136.

Sachidananda, S. (1970) The changing Munda. New Delhi: Concept Publishing Company.

Scott, J.C. (1985) Weapons of the weak. Everyday forms of peasant resistance. New Haven, Connecticut: Yale University Press.

Shah, S.A. (1995) Status of Indian Forestry - 1, Wastelands News XI(2): 14-31.

Shepherd, G. (1993a) Indigenous and participatory forest management and the role of external intervention. Paper presented at National Resources Institute workshop on Stakeholders and Tradeoffs, March 1993.

Shepherd, G. (1993b) Africa: Semi-arid and sub-humid regions, in D.A. Messerschmidt (ed.), Common forest resource management. Annotated bibliography of Asia, Africa and Latin America, pp. 99-192. Rome: Food and Agriculture Organisation.

Shiva, V. (1988) Staying alive: Women, ecology and survival in India. New Delhi: Kali for Women.

Singh, C. (1986) Common property and common poverty. India's forests, forest dwellers and the law. Delhi: Oxford University Press.

Sinha, S.C., J. Sen and S. Panchbhai (1969) The concept of diku amongst the tribes of Chota Nagpur, Man in India 49(2): 121-138.

Stott, P. and S. Sullivan (2000) Political ecology. Science, myth and power. London: Arnold.

Stuligross, D. (2001) A piece of land to call one's own: Multicultural federalism and institutional innovation in India. Unpublished PhD Dissertation, University of California, Berkeley, December 2001.

World Bank (2000) India: Alleviating poverty through forest development. Washington, DC: World Bank. 